\title{
PHOSPHATE GLASSES: FORMING, STRUCTURE and PROPERTIES
}

\author{
GAIDA SEDMALE, ULDIS SEDMALIS
}

Riga Technical University, Institute of Silicate Materials, Azenes Str.14/24, Riga LV 1048, Latvia

\begin{abstract}
$\underline{\text { Abstract }}$
The structure and some properties of the glasses in the ternary systems (I) $\mathrm{BaO} \cdot \mathrm{B}_{2} \mathrm{O}_{3}-\mathrm{xP}_{2} \mathrm{O}_{5}(\mathrm{x}=0 \ldots 60 \mathrm{~mol} . \%)$ and (II) $\mathrm{BaO} .2 \mathrm{P}_{2} \mathrm{O}_{5}\left(3 \mathrm{P}_{2} \mathrm{O}_{5}\right)-\mathrm{xSiO}_{2}(\mathrm{x}=0 . .40 \mathrm{~mol} \%)$ as well as in $\mathrm{SiO}_{2}-\mathrm{P}_{2} \mathrm{O}_{5}$ with molar ratio $\mathrm{SiO}_{2} / \mathrm{P}_{2} \mathrm{O}_{5}=1$ were studied. The structure of glasses were characterised by their Raman spectra and compared with the phases developing in the treatment process. The chemical durability and density also was used to characterise the changes in the structure of glasses. It is shown that glasses are formed by the same structural groupings which are developed in thermal treatment of starting compositions. The changes in the glass structure causes the first 5-10 mol.\% addition of other glass formers $\mathrm{P}_{2} \mathrm{O}_{5}$ or $\mathrm{SiO}_{2}$. For these glasses in system $\mathrm{I}$ in concentration range of $\mathrm{P}_{2} \mathrm{O}_{5} 25-33.3 \mathrm{~mol} \%$ there are being formed the weakly connected $\mathrm{BPO}_{4}, \mathrm{BO}_{3}$ and $\mathrm{BO}_{4}$ groups. It is shown that the most promising application by the modification of these glasses of $\mathrm{Al}_{2} \mathrm{O}_{3}$ are heat resistant coatings for $\mathrm{Nb}+1 \% \mathrm{Zr}$ alloys.
\end{abstract}

\section{Introduction}

The $\mathrm{P}_{2} \mathrm{O}_{5}$ containing glasses together with other glass former $\mathrm{B}_{2} \mathrm{O}_{3}$ or $\mathrm{SiO}_{2}$ (in the presence of $\mathrm{BaO}$ ) were studied to obtain high temperature protective coatings. Some structures (and properties) of borophosphate glasses with $\mathrm{BaO}$ have been investigated ${ }^{1-3}$. Structural problems of these glasses become more complicated because of the fact that apart from boron(phosphorus)-oxygen groups the presence of $\mathrm{BPO}_{4}$ is highly probable ${ }^{4}$.

Silicophosphate glasses in structural investigations may be divided into two groups. Some authors 5,6 consider that in silicophosphate glasses is formed a common Si-O-P network. Others ${ }^{7}$ propose that groups $\mathrm{SiO}_{4}$ and $\mathrm{PO}_{4}$ are very loosely connected and a common network of glasses is not formed. The main problem for the practical use these glasses is that structure of boro- and silicophosphate glasses is formed from units, which do not form stable structure and as follows also properties. Thus is restricting the practical application of these glasses. Usually, e.g., ${ }^{8}$ to improve the properties of these glasses they are modified by $\mathrm{Al}_{2} \mathrm{O}_{3}$.

The present study is about the structure and some properties of the glasses in the system $\mathrm{BaO}$ $\mathrm{B}_{2} \mathrm{O}_{3}\left(\mathrm{SiO}_{2}\right)-\mathrm{P}_{2} \mathrm{O}_{5}$. In this communication we report a) on the thermal processing of mixtures within the system (I) $\mathrm{BaO} \cdot \mathrm{B}_{2} \mathrm{O}_{3}-\mathrm{xP}_{2} \mathrm{O}_{5}$ with gradual increase of $\mathrm{x}=0$ to $60 \mathrm{~mol} \%$ and in the system $\mathrm{SiO}_{2}$ $\mathrm{P}_{2} \mathrm{O}_{5}$ with molar ratio $\mathrm{SiO}_{2} / \mathrm{P}_{2} \mathrm{O}_{5}=1, \mathrm{~b}$ ) on the structure of obtained (I) glasses and glasses within the system (II) $\mathrm{BaO} .2 \mathrm{P}_{2} \mathrm{O}_{5}\left(3 \mathrm{P}_{2} \mathrm{O}_{5}\right)-\mathrm{xSiO}_{2}$ with gradual increase of $\mathrm{x}=0$ to $40 \mathrm{~mol} \%$, c) heat resistant coatings for the oxygen protection of $\mathrm{Nb}$ and $\mathrm{Nb}+1 \% \mathrm{Zr}$ alloys on the base of these glasses.

\section{Experimental procedure}

Glasses were prepared and investigated using methods previously described ${ }^{8}$.Figure 1 shows the glass forming regions and compositions studied in this work for the boro- (I) and silicophosphate (II) systems. 


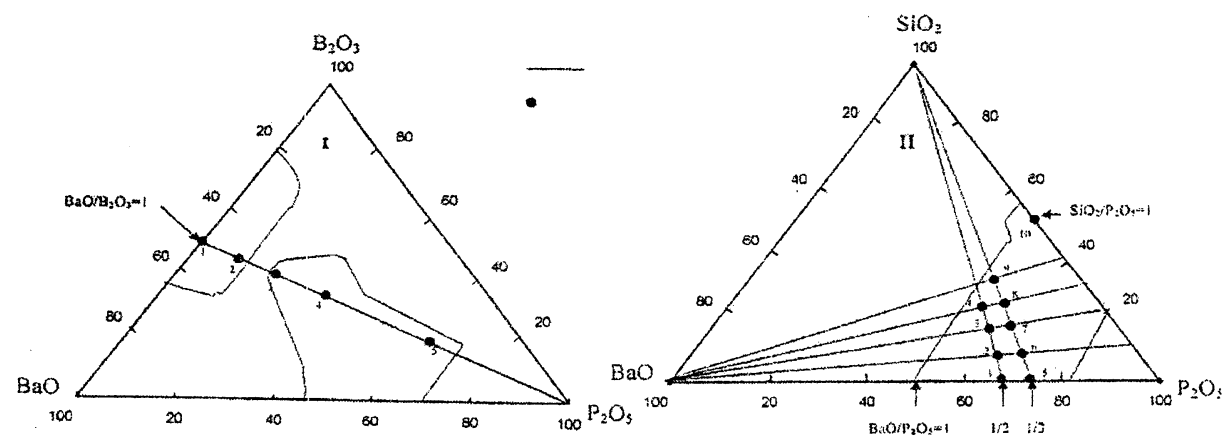

FIGURE 1. Glass formation regions (-) at $1200^{\circ} \mathrm{C}$ and various compositions ( $\bullet$ ) studied in the system I BaO. $\mathrm{B}_{2} \mathrm{O}_{3}-\mathrm{xP}_{2} \mathrm{O}_{5}(\mathrm{x}=0 . .60 \mathrm{~mol} . \%)$ and in the system (II) $\mathrm{BaO} .2 \mathrm{P}_{2} \mathrm{O}_{5}\left(3 \mathrm{P}_{2} \mathrm{O}_{5}\right)-\mathrm{xSiO}_{2}$ $(\mathrm{x}=0 . . .40 \mathrm{~mol} \%)$.

The coatings are produced by regular enamel technology using $50 \%$ suspension of particles $15-20 \mu \mathrm{m}$ in diameter in mixture of water+isopropanol. The efficiency of coatings have been controled by the changes of microhardness profile of alloys $\mathrm{Nb}+1 \% \mathrm{Zr}$ under the coatings after tests for $100 \mathrm{~h}$ at temperatures $\geq 850^{\circ} \mathrm{C}$.

\section{Results and Discussions}

The experimental results are interpreted on the assumption that the chemical compounds formed by the constituent parts in the glass melting process determine the structure and properties of the glasses and also the coatings obtained. Tables 1 and 2 summarise experimental results concerning the sequence of chemical compound development in the process of glass formation. The initial reaction of mixture of samples in system (I) and in $\mathrm{SiO}_{2} \cdot \mathrm{P}_{2} \mathrm{O}_{5}$ start at $300^{\circ} \mathrm{C}$ and form $\mathrm{BPO}_{4}$ (in system I), and $\mathrm{SiP}_{2} \mathrm{O}_{7}$ (system $\mathrm{II}$ ) in two crystalline modifications (cubic and monoclinic), and a changing compositions phase $\mathrm{xSiO}_{2} \cdot \mathrm{yP}_{2} \mathrm{O}_{5}$. The monoclinic $\mathrm{SiP}_{2} \mathrm{O}_{7}$ phase ceases to form at $700^{\circ} \mathrm{C}$. At $1200^{\circ} \mathrm{C}$ when a sufficient quantity of liquid phase is formed the presence of cubic $\mathrm{SiP}_{2} \mathrm{O}_{7}$ as well as the $\mathrm{xSiO}_{2} \cdot \mathrm{yP}_{2} \mathrm{O}_{5}$ crystalline phases is present.

In the system (I) excess $\mathrm{B}_{2} \mathrm{O}_{3}$ interacts with $\mathrm{BaO}$ at temperatures exceeding $700^{\circ} \mathrm{C}$ yielding metaborate $\mathrm{BaO} \cdot \mathrm{B}_{2} \mathrm{O}_{3}$. The increased $\mathrm{NH}_{4} \mathrm{H}_{2} \mathrm{PO}_{4}$ content, i.e., increased $\mathrm{P}_{2} \mathrm{O}_{5}$ content in composition (Fig.1) causes the formation of $\mathrm{BPO}_{4}$ at $300^{\circ} \mathrm{C}$ along with $3 \mathrm{BaO}, \mathrm{P}_{2} \mathrm{O}_{5}$ and $2 \mathrm{BaO} \cdot \mathrm{P}_{2} \mathrm{O}_{5}$ as well as a ternary compound $2 \mathrm{BaO} \cdot \mathrm{B}_{2} \mathrm{O}_{3} \cdot \mathrm{P}_{2} \mathrm{O}_{5}$. The ternary compound obtained at $900^{\circ} \mathrm{C}$ appears in composition 4 and is rather unstable and disproportionate at $1000^{\circ} \mathrm{C}$.

It should be noted that the crystalline phases development (system I) results at temperatures 1000$1100^{\circ} \mathrm{C}$ by the formation of $\mathrm{BaO} \cdot 4 \mathrm{~B}_{2} \mathrm{O}_{3}$ in addition to $\mathrm{BPO}_{4}$. Barium phosphates (samples 4 and 5) form at lower temperatures in range from $300-800^{\circ} \mathrm{C}$. In the binary $\mathrm{SiO}_{2}-\mathrm{P}_{2} \mathrm{O}_{5}$ system crystalline phases development results in cubic $\mathrm{SiP}_{2} \mathrm{O}_{7}$ and $\mathrm{xSiO} \cdot \mathrm{yP}_{2} \mathrm{O}_{5}$ formation. 
TABLE 1.Crysalline phases identified in the mixtures of investigated samples 1 to 5 of the system(I)

\begin{tabular}{|c|c|c|c|c|c|c|c|c|c|}
\hline \multirow{2}{*}{$\begin{array}{l}\text { Composition } \\
\text { (see fig.1) }\end{array}$} & \multicolumn{9}{|c|}{ Crystalline phases at varios temperatures $\left({ }^{\circ} \mathrm{C}\right)^{*}$} \\
\hline & 300 & 400 & 500 & 600 & 700 & 800 & 900 & 1000 & 1100 \\
\hline 1 & $\mathrm{BaC}, \mathrm{s}$ & $\mathrm{BaC}, \mathrm{w}$ & $\mathrm{BaC}, \mathrm{w}$ & $\mathrm{BaC}, \mathrm{vw}$ & $\mathrm{BaB}, \mathrm{s}$ & $\mathrm{BaB}, \mathrm{w}$ & $\mathrm{BaB}, \mathrm{w}$ & melt & \\
\hline 2 & $\begin{array}{l}\mathrm{BaC}, \mathrm{s} \\
\mathrm{BP}, \mathrm{w}\end{array}$ & $\begin{array}{l}\mathrm{BaC}, \mathrm{w} \\
\mathrm{BP}, \mathrm{w}\end{array}$ & $\begin{array}{c}\mathrm{BaC}, \mathrm{w} \\
\mathrm{BP}, \mathrm{w}\end{array}$ & $\begin{array}{c}\mathrm{BaC}, \mathrm{vw} \\
\mathrm{BP}, \mathrm{w}\end{array}$ & $\begin{array}{c}\mathrm{BaC}, \mathrm{vw} \\
\mathrm{BP}, \mathrm{w} \\
\mathrm{BaB}, \mathrm{w}\end{array}$ & $\begin{array}{c}\mathrm{BP}, \mathrm{w} \\
\mathrm{BaB}, \mathrm{w}\end{array}$ & $\begin{array}{l}\mathrm{BP}, \mathrm{w} \\
\mathrm{BaB}, \mathrm{w}\end{array}$ & melt & \\
\hline 3 & $\begin{array}{l}\mathrm{BaC}, \mathrm{s} \\
\mathrm{BP}, \mathrm{vw}\end{array}$ & $\begin{array}{l}\mathrm{BaC}, \mathrm{w} \\
\mathrm{BP}, \mathrm{w}\end{array}$ & $\begin{array}{c}\mathrm{BaC}, \mathrm{w} \\
\mathrm{BP}, \mathrm{w}\end{array}$ & $\begin{array}{l}\mathrm{BaC}, \mathrm{vw} \\
\mathrm{BP}, \mathrm{vw}\end{array}$ & $\begin{array}{l}\mathrm{BaC}, \mathrm{vw} \\
\mathrm{BP}, \mathrm{vw} \\
\mathrm{BaB}_{4, \mathrm{w}}\end{array}$ & $\begin{array}{c}\mathrm{BP}, \mathrm{w} \\
\mathrm{BaB}_{4}, \mathrm{w}\end{array}$ & $\begin{array}{c}\mathrm{BP}, \mathrm{w} \\
\mathrm{BaB}_{4}, \mathrm{w}\end{array}$ & melt & \\
\hline 4 & $\begin{array}{l}\mathrm{BaC}, \mathrm{s} \\
\mathrm{BP}, \mathrm{VW}\end{array}$ & $\begin{array}{l}\mathrm{BaC}, \mathrm{w} \\
\mathrm{BP}, \mathrm{vw}\end{array}$ & $\begin{array}{l}\mathrm{BaC}, \mathrm{w} \\
\mathrm{BP}, \mathrm{vw}\end{array}$ & $\begin{array}{l}\mathrm{BaC}, \mathrm{vw} \\
\mathrm{BP}, \mathrm{vw} \\
\mathrm{Ba}_{3} \mathrm{Pvw}\end{array}$ & $\begin{array}{l}\mathrm{BaC}, \mathrm{vw} \\
\mathrm{BP}, \mathrm{vw} \\
\mathrm{Ba}_{3} \mathrm{Pw}\end{array}$ & $\begin{array}{l}\mathrm{BP}, \mathrm{w} \\
\mathrm{Ba}_{3} \mathrm{Pw}\end{array}$ & $\underset{\mathrm{Ba}_{2} \mathrm{PBw}}{\mathrm{BP}, \mathrm{s}}$ & $\mathrm{BP}, \mathrm{s}$ & melt \\
\hline 5 & $\begin{array}{l}\mathrm{BP}, \mathrm{vw} \\
\mathrm{Ba}_{2} \mathrm{P}, \mathrm{w}\end{array}$ & $\begin{array}{c}\mathrm{BP}, \mathrm{w} \\
\mathrm{Ba}_{2} \mathrm{P}, \mathrm{w}\end{array}$ & $\mathrm{BP}, \mathrm{w}$ & $\mathrm{BP}, \mathrm{w}$ & $\mathrm{BP}, \mathrm{w}$ & $\mathrm{BP}, \mathrm{s}$ & $\mathrm{BP}, \mathrm{s}$ & $\mathrm{BP}, \mathrm{s}$ & melt \\
\hline
\end{tabular}

*) Symbols: $\quad \mathrm{BaC}=\mathrm{BaCO}_{3} ; \quad \mathrm{Ba} 3 \mathrm{~B}=3 \mathrm{BaO} \cdot \mathrm{B}_{2} \mathrm{O}_{3} ; \quad \mathrm{BaB}=\mathrm{BaO} \cdot \mathrm{B}_{2} \mathrm{O}_{3} ; \quad \mathrm{BaB}_{2}=\mathrm{BaO} \cdot 2 \mathrm{~B}_{2} \mathrm{O}_{3}$; $\mathrm{BaB}_{4}=\mathrm{BaO} .4 \mathrm{~B}_{2} \mathrm{O}_{3} ; \mathrm{Ba}_{3} \mathrm{P}=3 \mathrm{BaO} . \mathrm{P}_{2} \mathrm{O}_{5} ; \quad \mathrm{Ba}{ }_{2} \mathrm{P}=2 \mathrm{BaO} .3 \mathrm{P}_{2} \mathrm{O}_{5} ; \mathrm{BP}=\mathrm{BPO}_{4} ; \mathrm{s}=$ strong; $=$ =weak; vw=very weak.

TABLE 2. Crystalline phases identified in the mixtures of the system $\mathrm{SiO}_{2}-\mathrm{P}_{2} \mathrm{O}_{5}$ with molar ratio $\mathrm{SiO}_{2} / \mathrm{P}_{2} \mathrm{O}_{5}=1$

\begin{tabular}{|c|c|c|c|c|c|c|c|c|}
\hline \multicolumn{9}{|c|}{ Crystalline phases at varies temperatures $\left({ }^{0} \mathrm{C}\right)^{* *}$} \\
\hline 300 & 400 & 500 & 700 & 800 & 900 & 1000 & 1100 & 1200 \\
\hline \multicolumn{9}{|c|}{ SP,cub } \\
\hline \multicolumn{9}{|c|}{ SP,mon } \\
\hline \multicolumn{9}{|c|}{$\mathrm{S}_{\mathrm{x}} \mathrm{P}_{\mathrm{y}}$} \\
\hline
\end{tabular}

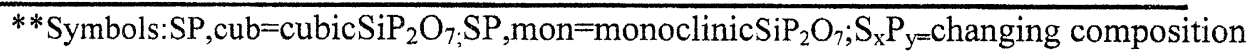
crystalline phase $\mathrm{xSiO}_{2} \cdot \mathrm{yP}_{2} \mathrm{O}_{5}$.

Figure 2 shows Raman spectra for glassy phases quenched from melt in system (I). The main changes of spectral lines are observed in the ranges of $800-500 \mathrm{~cm}^{-1}$ and $1300-900 \mathrm{~cm}^{-1}$. Their localisation and intensity change with the increase of $\mathrm{P}_{2} \mathrm{O}_{5}$ concentration in the glasses.

The spectral lines of glasses $\mathrm{BaO} \cdot \mathrm{B}_{2} \mathrm{O}_{3}$ are the result of the boron-oxygen oscillations in the $\mathrm{BO}_{3}$ groups. The first $5-10 \mathrm{~mol} \% \mathrm{P}_{2} \mathrm{O}_{5}$ addition causes changes in the position of spectral lines to 1100 $990 \mathrm{~cm}^{-1}$ and $700-620 \mathrm{~cm}^{-1}$. They are the result of formation of the bonds in orthophosphate groups ${ }^{3}$. Increase of $\mathrm{P}_{2} \mathrm{O}_{5}$ amount to $25-33.3 \mathrm{~mol} \%$ causes the dominant spectral bands at $1080-920 \mathrm{~cm}^{-1}$ and at $520-450 \mathrm{~cm}^{-1}$. These indicate on the formation of bonds in $\mathrm{BPO}_{4}, \mathrm{BO}_{3}$ and $\mathrm{BO}_{4}$ groups. In this concentration range of $\mathrm{P}_{2} \mathrm{O}_{5} 25-33.3 \mathrm{~mol} \%$ the formation of the greatest number of oscillations is observed. This corresponds to glasses with a low stability in this range of $\mathrm{P}_{2} \mathrm{O}_{5}$. The chemical durability for these glasses is the lowest, i.e., the weight losses considerably increase, Fig.4. At $\mathrm{P}_{2} \mathrm{O}_{5}$ contents above 40-50 mol.\% spectra are somewhat simpler and exibit relatively broad features. The main oscillations are due to $\mathrm{PO}_{3}$ groups as well as $\mathrm{BPO}_{4}$. The chemical durability of these glasses increase (weight losses decrease), Fig. 4. 


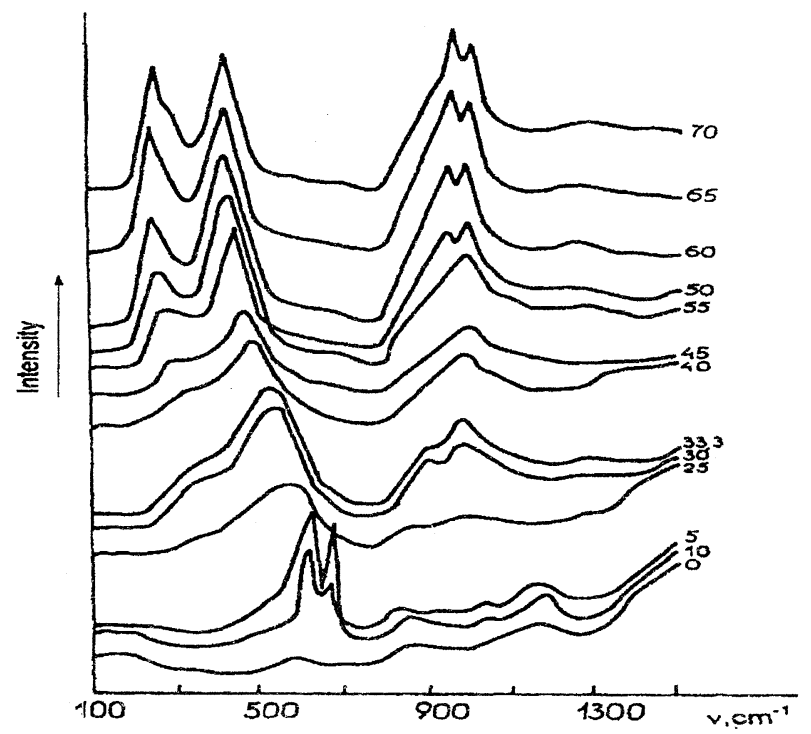

FIGURE 2. Raman spectra of $\mathrm{BaO} \cdot \mathrm{B}_{2} \mathrm{O}_{3}-\mathrm{xP}_{2} \mathrm{O}_{5}$ glasses. The $\mathrm{P}_{2} \mathrm{O}_{5}$ concentration in mol.\% identifies each spectrum.

The Raman spectra (Fig.3) of glasses with molar ratio $\mathrm{SiO}_{2} / \mathrm{P}_{2} \mathrm{O}_{5}=1$ show the formation of the bond $\mathrm{P}=\mathrm{O}$ with the oscillation at $1330 \mathrm{~cm}^{-1}$. After the thermal treatment of these glasses this oscillation decrease and a band at $330 \mathrm{~cm}^{-1}$ appears This is characteristic for group $\mathrm{SiO}_{6}{ }^{5,6}$.

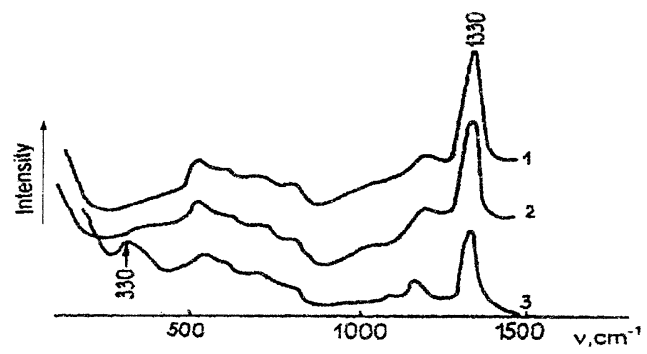

FIGURE 3. Raman spectra of glasses with molar ratio $\mathrm{SiO}_{2} / \mathrm{P}_{2} \mathrm{O}_{5}=1: 1$-quenched from melt; 2annealed at $500^{\circ} \mathrm{C} 7 \mathrm{~h}, 3$ - annealed at $700^{\circ} \mathrm{C} 7 \mathrm{~h}$.

The density dependence (Fig.4) on $\mathrm{SiO}_{2}$ content in these glasses by presence of $\mathrm{BaO}$ shows that in the presence of other oxide glass building agent over 5-10 mol.\% causes the shift of those characteristics away from linearity. It indicates the changes in the glasses structure and as follows from $^{9}$ to the formation of P-O-Si links.

It can be imagine that the introduction of small amounts (up to $5 \%$ ) of $\mathrm{SiO}_{2}$ in to the $\mathrm{Ba}$ methaposphate glasses may form dipploid structure of tetrahedral $\mathrm{SiO}_{4}$ between linear poliphosphate (type A, see scheme). In this case there is a crosslinks between linear poliphosphate. A bound glass 
structure is formed. The density of glasses increasses. At $\mathrm{SiO}_{2}$ content above $10-15 \mathrm{~mol} \%$ the structure of type B (see scheme) may form with three bridging oxygens, i.e., structural links are weakened ${ }^{9}$.
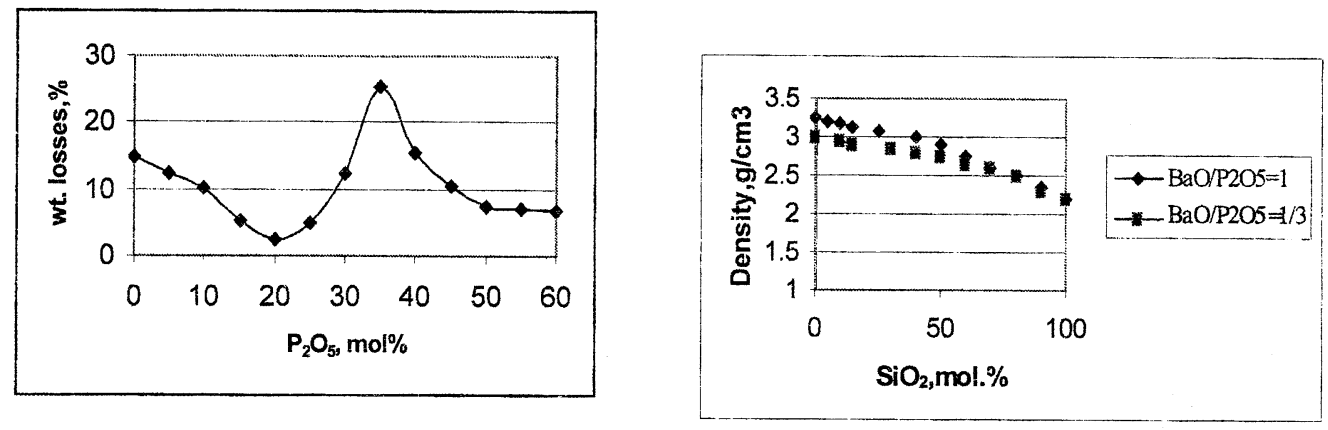

FIGURE 4. The chemical inertness of the glasses in system $\mathrm{BaO} \cdot \mathrm{B}_{2} \mathrm{O}_{3}-\left(0 \ldots 60 \mathrm{P}_{2} \mathrm{O}_{5}\right)$ and the density of the glasses in system II: 1 -in across section by $\mathrm{BaO} / \mathrm{P}_{2} \mathrm{O}_{5}=1 / 2$ and $2-$ by $\mathrm{BaO} / \mathrm{P}_{2} \mathrm{O}_{5}=1 / 3$.<smiles>CP(C)(C)(C)O[Si](OP(C)(C)(C)C)(OP(C)(C)(C)C)OP(C)(C)(C)C</smiles>

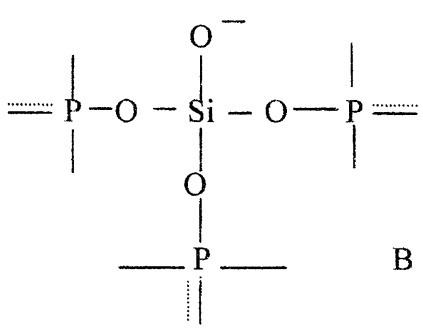

The most promising application area of investigated glasses are coatings. Therefore to optimise coatings output formed on surface $\mathrm{Nb}-\mathrm{Zr}$ alloys (as well as on $\mathrm{Fe}-\mathrm{Co}$ alloys) formed by temperatures $1050 \ldots 1150^{\circ} \mathrm{C}$ in vacuum at $\mathrm{p}=10^{-3}-10^{-4} \mathrm{~Pa}$ of the given glasses several factors must be taken into account. Amongst these as a primary are: chemical durability of basic glasses, adhesion to the surface of substrata in vacuum in the temperature range $\geq 850^{\circ} \mathrm{C}$, insignificant interaction with the substrata. Therefore the glasses in the system $\mathrm{BaO}-\mathrm{SiO}_{2}\left(\mathrm{~B}_{2} \mathrm{O}_{3}\right)-\mathrm{P}_{2} \mathrm{O}_{5}$ were modified by $\mathrm{Al}_{2} \mathrm{O}_{3}$. When the molar ratio in the glasses is $\mathrm{Al}_{2} \mathrm{O}_{3}: \mathrm{SiO}_{2}: \mathrm{P}_{2} \mathrm{O}_{5} \sim 1$ forms a strong bonded glass structure. This allows to develop vitreous heat resistant coatings with the following ingredients in composition (wt.\%): $\mathrm{BaO} 33 \ldots 40, \mathrm{MgO} 0 \ldots 15, \mathrm{Al}_{2} \mathrm{O}_{3} 17 \ldots 25, \mathrm{~B}_{2} \mathrm{O}_{3} 0 \ldots 5, \mathrm{SiO}_{2} 12 \ldots 26$ and $\mathrm{P}_{2} \mathrm{O}_{5}$. The coatings by the melting temperature have an excellent adhesion to surface of $\mathrm{Nb}-\mathrm{Zr}$ alloys in vacuum.Optimal thickness of coating is $40-50 \mu \mathrm{m}$. During the melting process between metall and coating a $4-6 \mu \mathrm{m}$ thick dense crystalline diffusion interlayer (mainly from oxygen free NbP crystalls) is formed. The structure of this zone differs from the glassy coating and metal. The changes of microhardness profile under the glassy coatings after tests for $100 \mathrm{~h}$ at temperatures $\geq 850^{\circ} \mathrm{C}$ in oxygen environment 
shows (Fig. 5) that diffusion of oxygen in substrata could be observed in very short zone as a result of coatings technological process.

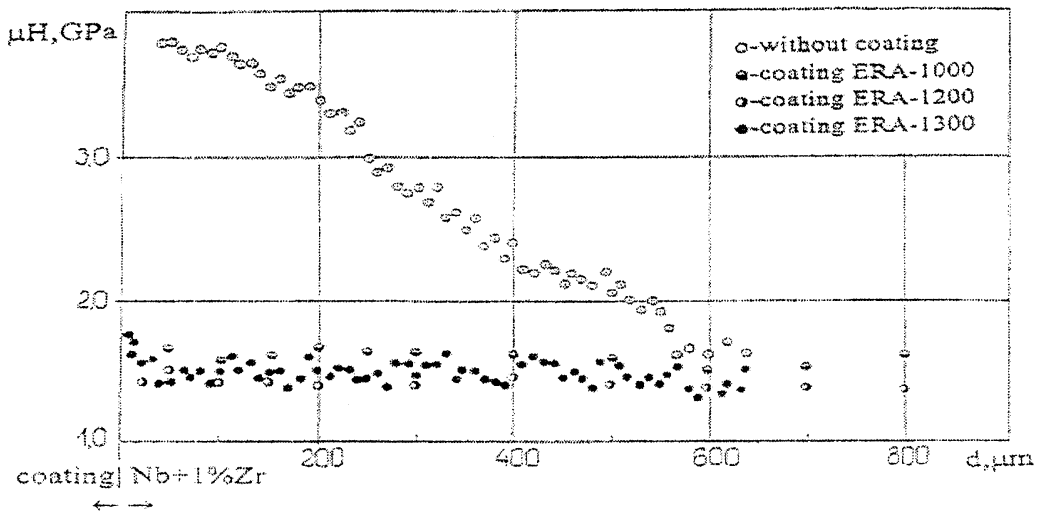

FIGURE 5. Microhardness profile for glassy coatings - $\mathrm{Nb}+1 \% \mathrm{Zr}$ after tests

These shows that both the formed vitreous coating as well as the crystalline interlayer formed are effective bariers to oxygen diffussion, thus protecting $\mathrm{Nb}-\mathrm{Zr}$ alloy at elevated temperature (above $750{ }^{\circ} \mathrm{C}$ ).

\section{Conclusions}

The compounds developming in the glass melting process of $\mathrm{P}_{2} \mathrm{O}_{5}$ containing systems (I) $\mathrm{BaO} . \mathrm{B}_{2} \mathrm{O}_{3}-\mathrm{xP}_{2} \mathrm{O}_{5}(\mathrm{x}=0 . \ldots 60 \mathrm{~mol} \%)$ and (II) $\mathrm{BaO}-\mathrm{SiO}_{2}-\mathrm{P}_{2} \mathrm{O}_{5}$-system by molar ratio of $\mathrm{SiO}_{2} / \mathrm{P}_{2} \mathrm{O}_{5} \leq 1$ were studied. It is shown that glasses are formed by the same structural groupings which are developed in thermal treatment of starting compositions. Introduction of 5-10mol.\% of the others glass builders $\left(\mathrm{P}_{2} \mathrm{O}_{5}\right.$ or $\left.\mathrm{B}_{2} \mathrm{O}_{3}\right)$ in the compositions of the glasses I and II causes considarable changes of structure. For practilly application it is important to modify these glasses by $\mathrm{Al}_{2} \mathrm{O}_{3}$. Conducted tests proved that glasses at the precence of $\mathrm{Al}_{2} \mathrm{O}_{3}$ and by molar ratio of $\mathrm{Al}_{2} \mathrm{O}_{3}: \mathrm{SiO}_{2}: \mathrm{P}_{2} \mathrm{O}_{5} \sim 1$ are promising materials for heat and oxygen corrosion resistant protective coatings on $\mathrm{Nb}-\mathrm{Zr}$ alloys at temperatures above $750^{\circ} \mathrm{C}$.

\section{References}

1. V.A.Kolesova, Phys. and Chem. of Glasses, 3, 5, 257 (1983) (in Russian).

2. P.Ramamoorthy, J.Rockettt, J.Am.Ceram.Soc. 57,.501 (1974).

3. G.Sedmale, J.Vaivads, U.,Sedmalis,V.O.Kabanov, O.VYanush.,J.Non-Cryst.Sol. 29.284 (1991).

4. N.H.Ray, Phys. and Chem.of Glasses 16, 75 (1975).

5. C.W.F. Finn, D.J Fray., T.B. King., J.G. Ward, Phys.and Chem.of Glasses 17,3, 71(1976).

6. F.J. Ryerson, P.C Hess, Geochem. Cosmochem. Acta 44,4.611(1980).

7. V.A. Kolesova., A.E. Malishova. Phys. and Chem.of Glasses 10, 6,641 (1984).

8. G .Sedmale, V. Kabanov, U. Sedmalis, Fundamentals of Glass Science and Technology. Glastechn.Ber.Glass Sci.Technol, 68C1, 79 (1995).

9. J.A.Vaivads., S.J.Lagzdina, U.J Sedmalis, Phys. and Chem. of glass system, 5.29 (1977) (in Russian). 